\title{
CHARACTERIZATION OF THE THERMAL ENVIRONMENT IN BROILER HOUSES WITH DIFFERENT CLIMATE CONTROL SYSTEMS
}

\author{
Carlos G. de S. Teles Junior ${ }^{*}$, Richard S. Gates ${ }^{2}$, Cecilia de F. Souza ${ }^{1}$, \\ Ilda de F. F. Tinôco' ${ }^{1}$, Monique de O. Vilela ${ }^{1}$
}

\begin{abstract}
${ }^{1 *}$ Corresponding author. Departamento de Engenharia Agrícola da Universidade Federal de Viçosa/ Viçosa - MG, Brasil. E-mail: carlosgutembergjr@gmail.com | ORCID ID: https://orcid.org/0000-0002-3519-0938
\end{abstract}

\section{KEYWORDS \\ broiler thermal demand, cooling, heating, thermal environment management.}

\begin{abstract}
The environment control of broiler houses must be done adequately to provide good thermal conditions to broilers without wasting energy. The objective of this study was to characterize the thermal environment in two mechanically ventilated broiler houses with a negative pressure ventilation system, one with a cellulose pad evaporative cooling system and the other with misting nozzles for evaporative cooling. The experiment was conducted in Ervália-MG during winter, spring, and summer. The thermal environment was characterized based on the relationship between the temperature observed inside the broiler houses and the temperatures recommended for the thermal comfort of birds of different ages. The recorded data were evaluated using descriptive statistics, and the spatial variation of the average temperature data recorded during the growth phase in both broiler houses was evaluated graphically using contour graphs. During the brooding phase, the temperatures recorded in both broiler houses were above the recommended values $\left(27-30{ }^{\circ} \mathrm{C} ; 24-27{ }^{\circ} \mathrm{C}\right.$; and $21-24{ }^{\circ} \mathrm{C}$, for the $1^{\text {st; }} 2^{\text {nd }}$ and $3^{\text {rd }}$ weeks of bird life respectively) during the entire evaluation period. In the growout phase, it was found that during winter and spring, the interior temperature was within the recommended range $\left(15-27^{\circ} \mathrm{C}\right)$, however, in summer, there were periods when the interior temperature was above the comfort range of birds.
\end{abstract}

\section{INTRODUCTION}

The Brazilian poultry industry is currently one of the most developed in the world and has grown steadily in recent years owing to advances in genetics, nutrition, and animal health, as well as the modernization of breeding facilities (Neves et al. 2010). Modern and efficient design methodology of animal barns considers the environment and animal welfare, with a view of proper production management (Silva \& Vieira, 2010; Schmidt \& Silva, 2018).

Santos et al. (2017) stated that these advances in genetics and breeding have resulted in better productive performance of the birds, resulting in significant improvement in weight gain over the last decades. However, this process have also had an adverse effect on the production system because the evolution in the weight gain of animals hinders their thermal exchange with the environment, increasing the need to use climate control systems on higher-temperatures days (Costa et al., 2012).

To minimize the effects of thermal stress on broilers, some thermal conditioning systems are used to provide comfortable thermal conditions for the birds' development where they are housed (Mascarenhas et al., 2018). Bueno \& Rossi (2016) studied thermally conditioned facilities, those equipped with ventilation, exhaust fans, misting, and evaporative cooling panels, whose objective was to achieve thermal comfort inside the barn regardless of the external climate condition.

Regarding thermal comfort conditions for broilers, a temperature range of $26-34{ }^{\circ} \mathrm{C}$ in the brooding phase and between $19-25^{\circ} \mathrm{C}$ in the growout phase was considered (Oliveira et al., 2006; Abreu \& Abreu, 2011). However, studies show that these values can be optimized. It was observed that temperatures ranging from $21-30{ }^{\circ} \mathrm{C}$ in the brooding phase and from $15-27{ }^{\circ} \mathrm{C}$ in the growout phase

${ }^{1}$ Departamento de Engenharia Agrícola da Universidade Federal de Viçosa/ Viçosa - MG, Brasil.

${ }^{2}$ Department of Agricultural and Biosystems Engineering and Animal Science, Egg Industry Center, Iowa State University/Ames, USA.

Area Editor: Héliton Pandorfi

Received in: 12-9-2019

Accepted in: 6-30-2020 
were acceptable for the thermal comfort of the birds without compromising their productive performance (Medeiros et al., 2005; Cassuce et al., 2013; Cândido et al., 2016). This improvement in the broiler thermal comfort range may present potential savings for poultry farmers as the higher costs in the broiler production system are related to the thermal control of the barn, both in the brooding and growout phases.

Given the importance of these thermal conditioning systems in mitigating the effects of the harmful thermal environment for birds, correct sizing and proper installation of these systems is of paramount importance (Santos et al., 2009). In this sense, according to Curi et al. (2014a), a knowledge of the variation of the thermal factors, in particular, temperature and relative humidity inside the barns, is essential to assist in the design and management of the adopted climate control system.

The thermal characterization of broiler houses can be based on the relationship between the average hourly temperatures observed inside the barns and those recommended for the comfort of broilers at different stages of the production cycle, during the different climatic seasons of the year.

Based on the above aspects, this study aimed to characterize the thermal environment in two mechanically ventilated broiler houses with a negative pressure ventilation system, one with a cellulose pad evaporative cooling system (NPVEP), and the other with misting nozzles for evaporative cooling (NPVN).

\section{MATHERIAL AND METHODS}

The experiment was carried out in a commercial broiler farm located in the municipality of Ervália, Minas Gerais, located in the Zona da Mata Mineira, in the Viçosa microregion. The study area has an average altitude of $730 \mathrm{~m}$ and a subtropical climate of altitude (Cwa). The study was carried out over three seasons: winter, spring, and summer. These correspond to the coldest season, the transition season, and the hottest season of the year, respectively.

The farm consisted of two broiler houses (barns), each with a capacity of 30,000 broilers/flock, $12 \mathrm{~m}$ wide by $145 \mathrm{~m}$ long and $3 \mathrm{~m}$ high. In addition, the roof had fiber cement tile and polyurethane lining. The end walls were masonry, and the side closure used polyurethane curtains. Each barn was also equipped with an automatic feed distribution system and nipple drinkers.

The thermal environment management in the barns was divided into two phases: the brooding phase and the growout phase. The brooding phase comprises the first 15 to $18 \mathrm{~d}$ of bird life. On the other hand, the growout phase is the period from the end of the brooding to the start of slaughter, which occurs between the $42^{\text {nd }}$ and $45^{\text {th }}$ day. The characteristics of the thermal conditioning system used in each of the studied barns are described below.
- Barn negative pressure ventilation plus evaporative pad (NPVEP): A negative pressure tunnel ventilation system was used with 8 exhaust fans of $1.27-\mathrm{m}$ diameter with an air discharge cone and a motor with a power of $1.1 \mathrm{~kW}$. The flow rate provided by each exhaust fan varied according to the static pressure in the barn, depending on the manufacturer's manual (Plasson do Brasil, 2020). There were four fan stages with two exhaust fans in each stage. During the brooding phase, only one fan stage worked (two exhaust fans) providing four to six cycles of air change per hour in the barn. During the growth phase, the number of fan stages operating at the same time varied according to the temperature variation inside the facility. Evaporative cooling was provided through cellulose pads installed in the air inlets of the tunnel ventilated barn. Supplemental heat was provided using a wood-fired furnace with an automatic feed system. This heating system was installed outside and adjacent to the barn, and hot air was distributed to the barn interior by means of perforated polyethylene pipes of $0.85 \mathrm{~m}$ diameter. Wood chips were used as the fuel source.

- Barn negative pressure ventilation plus misting (NPVN): A negative pressure tunnel ventilation system was used with 8 exhaust fans of 1.27-m diameter with an air directional cone and a motor with a power of $0.74 \mathrm{~kW}$. The flow rates varied according to the static pressure inside the facility (similar to NPVEP), but with values on average $15 \%$ lower than those specified for the exhaust fans used in the facility described above. The fan stages and ventilation management adopted for the brooding and growth phase in the NPVN are similar to those used for the NPVEP described above. Evaporative cooling was provided with 16 lines of nozzles with 8 misting nozzles per line, uniformly distributed along the barn length. The heating system was composed of an external furnace with a manual fuel feed and a heat distribution similar to that of the system used in NPVEP. Firewood was used as the fuel source.

The thermal environment inside each barn was compared with the recommended temperature for broiler thermal comfort at different stages of their production cycle. The recommended brooding temperatures were adopted from Cassuce et al. (2013) and Cândido et al. (2016), and they are $27-30{ }^{\circ} \mathrm{C}, 24-27{ }^{\circ} \mathrm{C}$, and $21-24^{\circ} \mathrm{C}$ for the $1^{\text {st }}, 2^{\text {nd }}$, and $3^{\text {rd }}$ week of brooding, respectively. For the growout phase $\left(4^{\text {th }}-6^{\text {th }}\right.$ weeks $)$, the thermal comfort temperature range of the birds was $15-27{ }^{\circ} \mathrm{C}$, according to the recommendations of Tinôco (2001) and Medeiros et al. (2005).

In the brooding phase, the temperature and relative humidity were collected at several points along the barn in the broilers' occupation area at bird-level height, approximately $50 \mathrm{~cm}$ above the floor. The number of data collection points (temperature and humidity) changed as a function of the increased broiler occupation area, which occurred gradually over the three-week brooding phase, ranging from 10 to 21 points, as shown in Figure 1. 

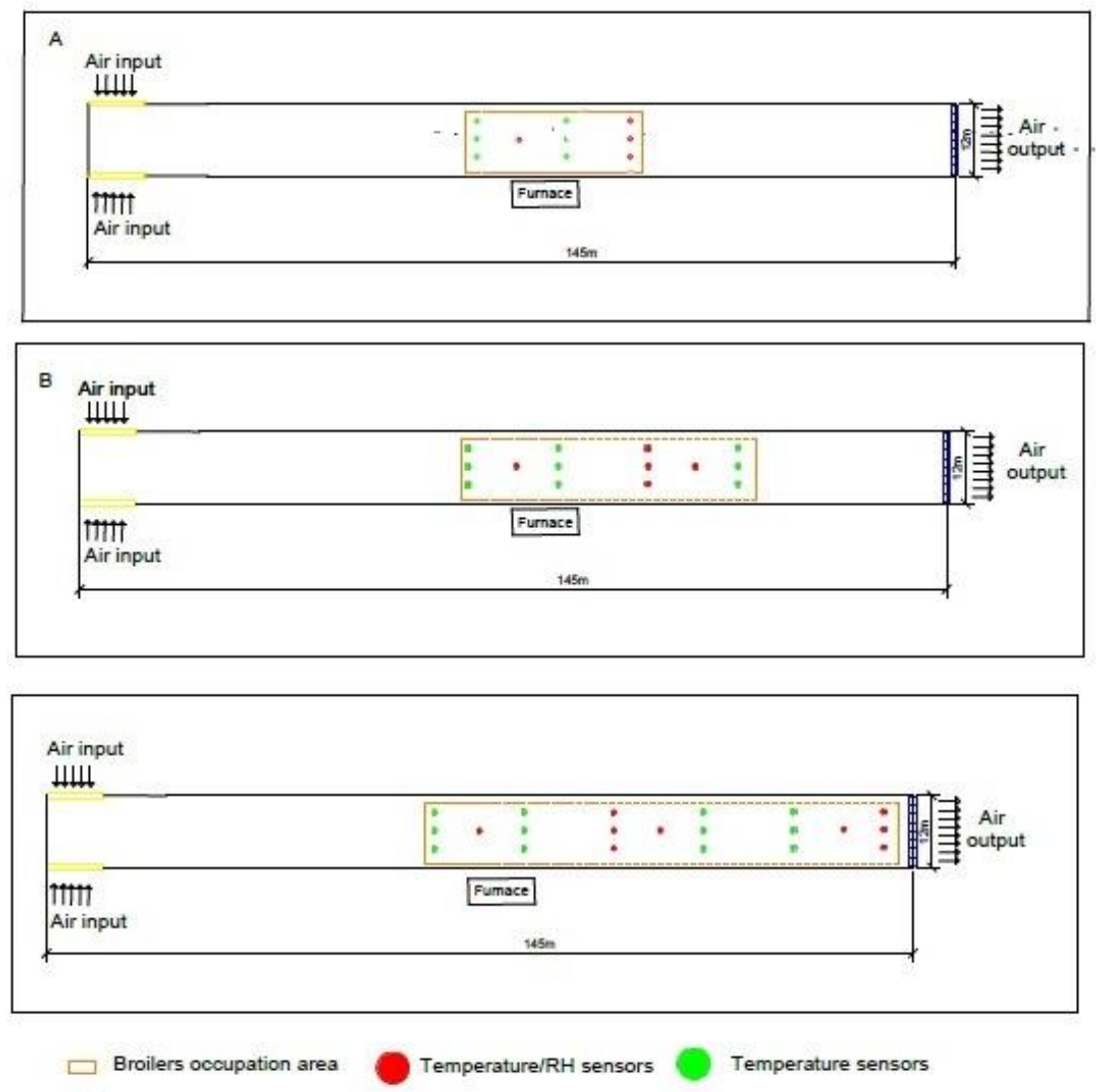

FIGURE 1. Arrangement of the temperature and temperature/relative humidity sensors in the broiler occupied zone inside the studied barns during brooding: [A] Week 1; [B] Week 2; [C] Week 3.

In the growout phase, the two barns were divided into three regions (air inlet, central, and air outlet). As shown in Figure 2, the climatic variables (temperature and relative air humidity) were recorded at 33 points in these regions at the height of the bird level.

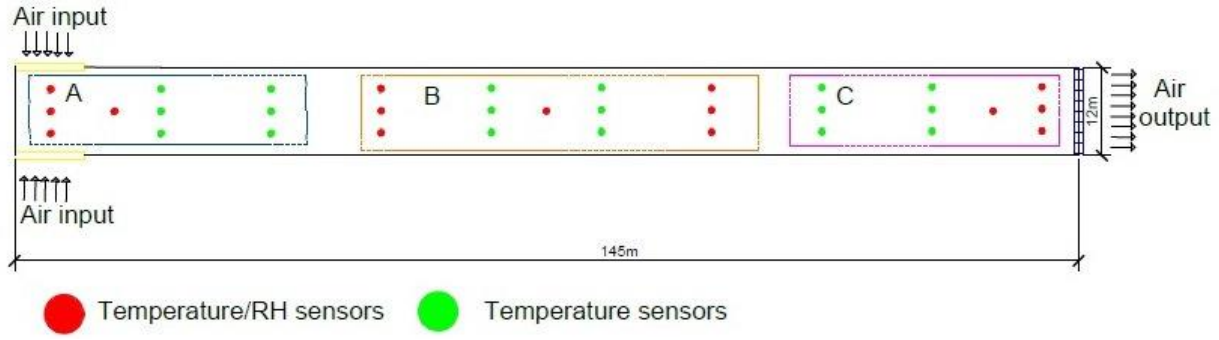

FIGURE 2. Arrangement of the temperature and temperature/relative humidity sensors inside the studied aviaries, during the growout phase in the: [A] Air inlet; [B] Central region; [C] Air outlet.

The DHT22 model (DHT type digital sensor) temperature/relative humidity sensors used have an accuracy of $\pm 0.5{ }^{\circ} \mathrm{C}$ for temperature and $\pm 2 \%$ for humidity, and a resolution of $0.1{ }^{\circ} \mathrm{C}$ for temperature and $0.1 \%$ for humidity. The DS18b20 model (digital sensor) temperature sensors used has a precision of $\pm 0.5^{\circ} \mathrm{C}$ and communicated with the data acquisition system through the One-Wire protocol. The air temperature and relative humidity data collected at different points were recorded at 1-min intervals over the entire bird production cycle, totaling $42 \mathrm{~d}$ in each evaluated flock (winter, spring, and summer).

In addition to the barn thermal environment data for each flock, the temperature and relative humidity data were also collected for the air outside the barns with the aid of a temperature and humidity data logger $\mathrm{Hobo}^{\circledR}$ model U14 -001. The device was protected from direct solar radiation and stored in a meteorological shelter installed just outside the barns. These data were used to characterize the weather experiments in the region where the broiler houses were located.

Data were summarized into hourly averages by week of age to evaluate the environmental conditions. These data referring to the climatic conditions in the studied facilities were evaluated graphically using descriptive statistics. The average temperature at each recorded location during growout was computed to assess the spatial variability in each broiler house, which was evaluated graphically using contour graphics.

\section{RESULTS AND DISCUSSION}

The relationship between the average hourly inside temperature observed in the broiler occupied zone, the average hourly outside temperature, and the recommended ideal temperature range for broiler thermal comfort during brooding can be seen in Figure 3, for each flock (winter, spring, and summer). 

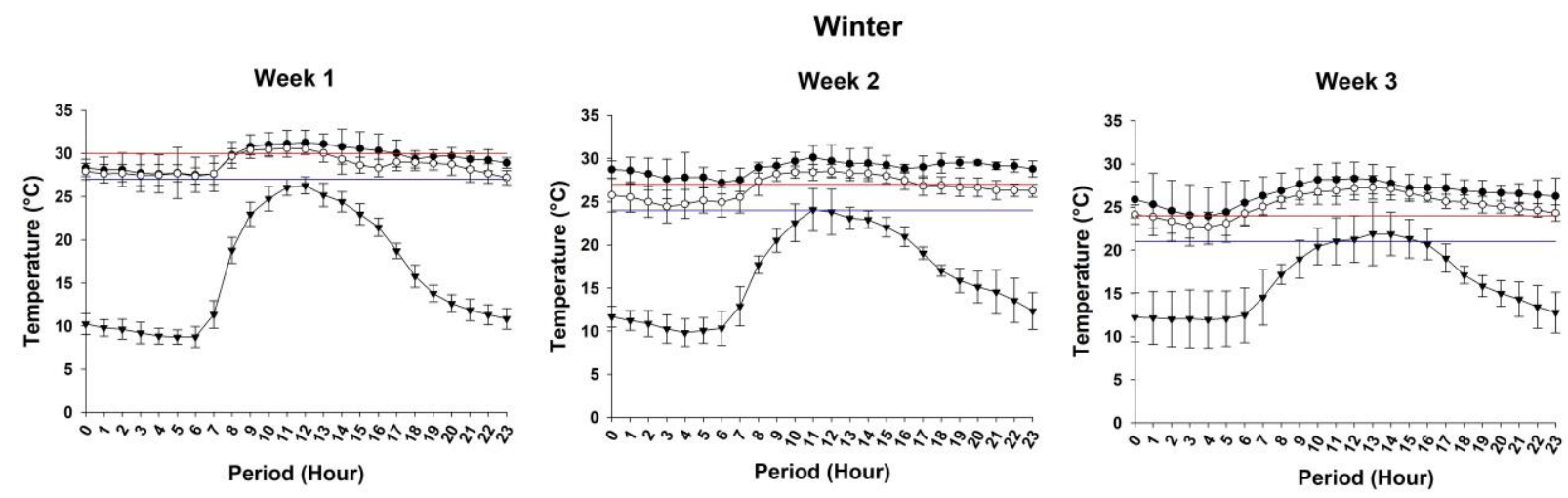

Spring
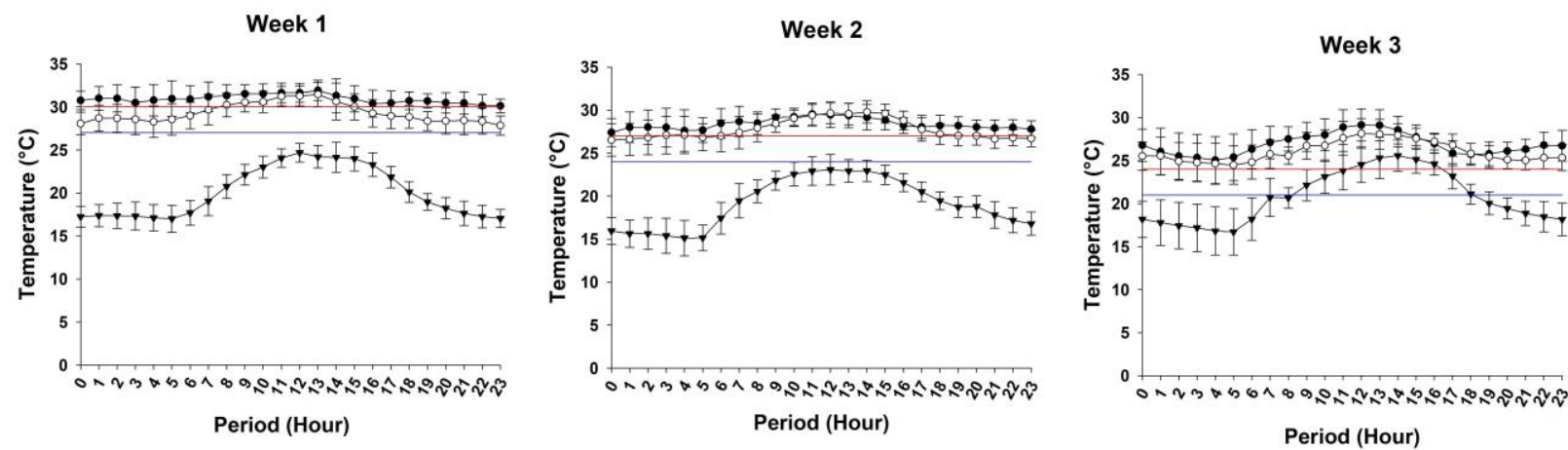

Summer
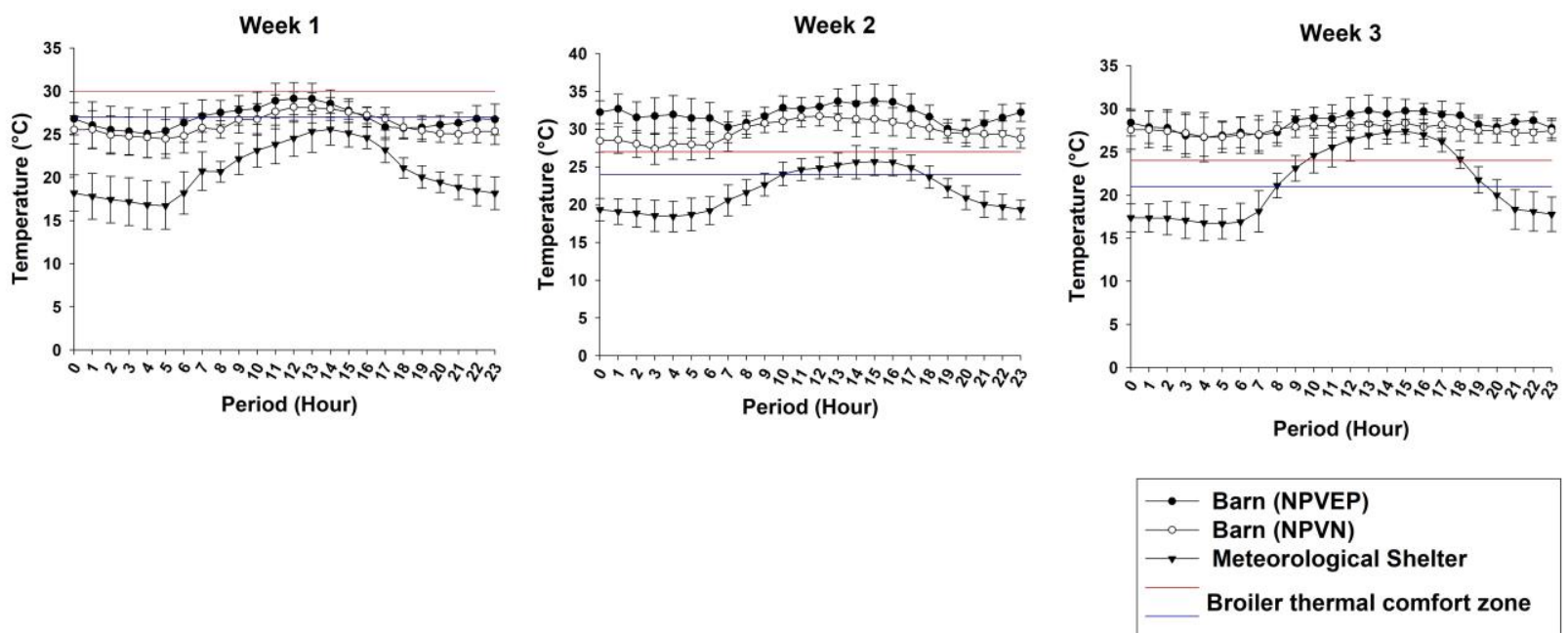

FIGURE 3. Relationship between the average hourly temperature observed in the broiler occupied zone, the average hourly outside temperature, and the temperature ranges recommended by Cassuce et al. (2013) and Cândido et al. (2016) for broiler thermal comfort in each of the three weeks of brooding for each of the three evaluated flocks.

During winter, the average hourly temperatures recorded in the broiler occupied zone during the first week of brooding remain predominantly within the recommended temperature range. For the second and third weeks of brooding, the average hourly temperatures in both barns exceed the upper temperature limit. For the spring and summer flocks, the average hourly temperatures are consistently above the upper limit temperature, especially for the second and third weeks of brooding and always for the NPVEP barn.

The ideal temperature range traditionally recommended in the literature states that the thermal comfort of broilers during brooding ranges from $32-34{ }^{\circ} \mathrm{C}$, 28-32 ${ }^{\circ} \mathrm{C}$, and $26-28{ }^{\circ} \mathrm{C}$ in the first, second, and third weeks, respectively (Medeiros et al., 2005; Oliveira et al., 2006; Abreu \& Abreu, 2011). According to the lineage manual, this range is $30-33{ }^{\circ} \mathrm{C}, 29-31{ }^{\circ} \mathrm{C}$, and $27-29{ }^{\circ} \mathrm{C}$ for the consecutive 3 weeks (Hubbard, 2016). Considering these traditionally used brooding temperatures, it can be seen that in all their flocks, there were periods where the average hourly temperature was below the thermal comfort range. This occurred mainly in the early hours of the day, and more frequently in the first week of the brooding phase and in the NPVN barn. 
Cassuce et al. (2013) and Cândido et al. (2016) showed that broilers in the brooding phase can tolerate lower temperatures than those traditionally recommended in the literature, without compromising their production performance. Another study done by Schiassi et al. (2015) corroborated the ability of broilers to tolerate lower temperatures than those traditionally used in the brooding phase. In this study, the researchers evaluated the behavioral patterns of broilers in the brooding phase, subjected to different thermal conditions, and found that at $33{ }^{\circ} \mathrm{C}$ and $30{ }^{\circ} \mathrm{C}$ for the first and second week brooding, respectively (values traditionally found in the literature as a reference for thermal comfort for birds at this age), the chicks showed typical behaviors of thermal discomfort, such as increased presence at the drinker and reduced presence at the feeder.

One of the biggest difficulties in broiler production is the maintenance of an appropriate temperature for brooding in these first weeks. Birds need elevated temperatures, and those commonly found in Brazil are below ideal conditions. This necessitates additional heating for the birds provided by the poultry farmer, thereby increasing the operating costs of broiler farms. This improvement of the standard temperature values for the heating recommendation of the barn, based on the results obtained by Cassuce et al. (2013) and Cândido et al. (2016), may represent an improvement in the final composition of the production cost of Brazilian poultry farms.
Based on the data obtained in the present research, it was observed that the poultry farmer worked to achieve the temperatures traditionally recommended in the literature. However, it was also observed that these temperature values were often above the lower comfort range indicated by Cassuce et al. (2013) and Cândido et al. (2016), indicating that there is an opportunity for the poultry farmer to lower temperatures during brooding and reduce operating costs.

Although the literature cited above showed the feasibility of using lower temperatures during brooding without lowering the productive performance of broilers, the vast majority of broiler farmers still fear adopting these values as a reference for heating their poultry houses. Therefore, extensive work is needed to convince the poultry farmers that it is possible to lower temperatures during the brooding phase without reducing the productivity of the broilers and provide an opportunity to reduce the costs of heating barns.

After the brooding phase, the growout phase began and lasted for $42 \mathrm{~d}$ until slaughter. The relation among the average hourly inside temperature, the average hourly outside temperature, and the recommended ideal temperature range (according to Tinôco (2001) and Medeiros et al. (2005)) for the three flocks (winter, spring, and summer) are provided in Figure 4. 

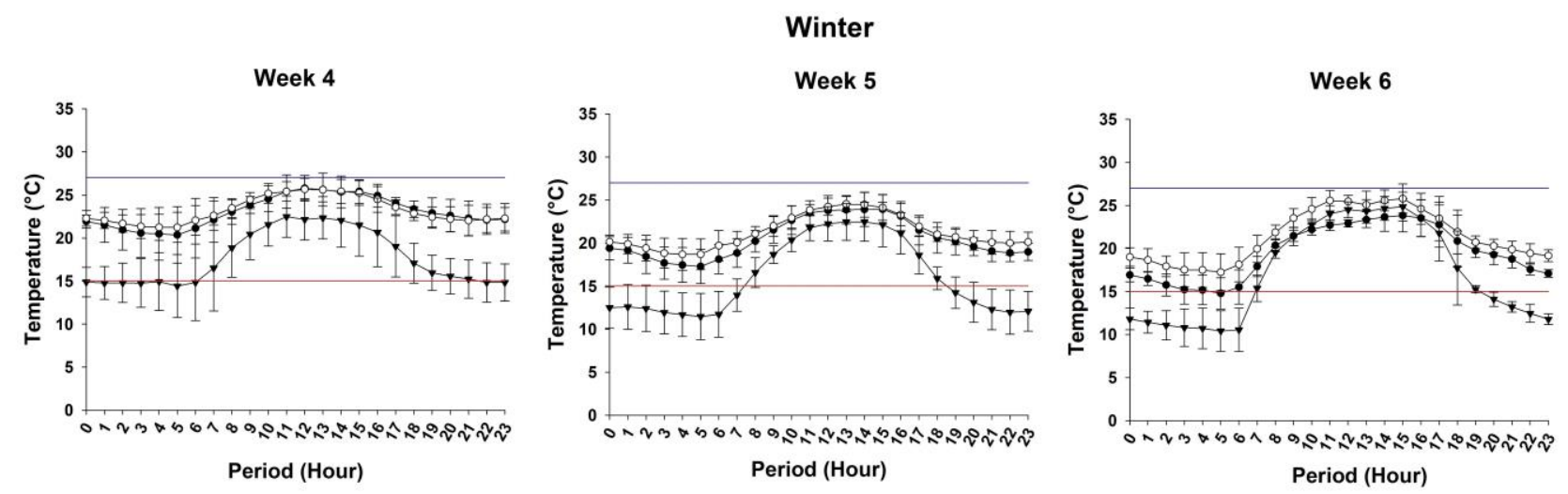

Spring
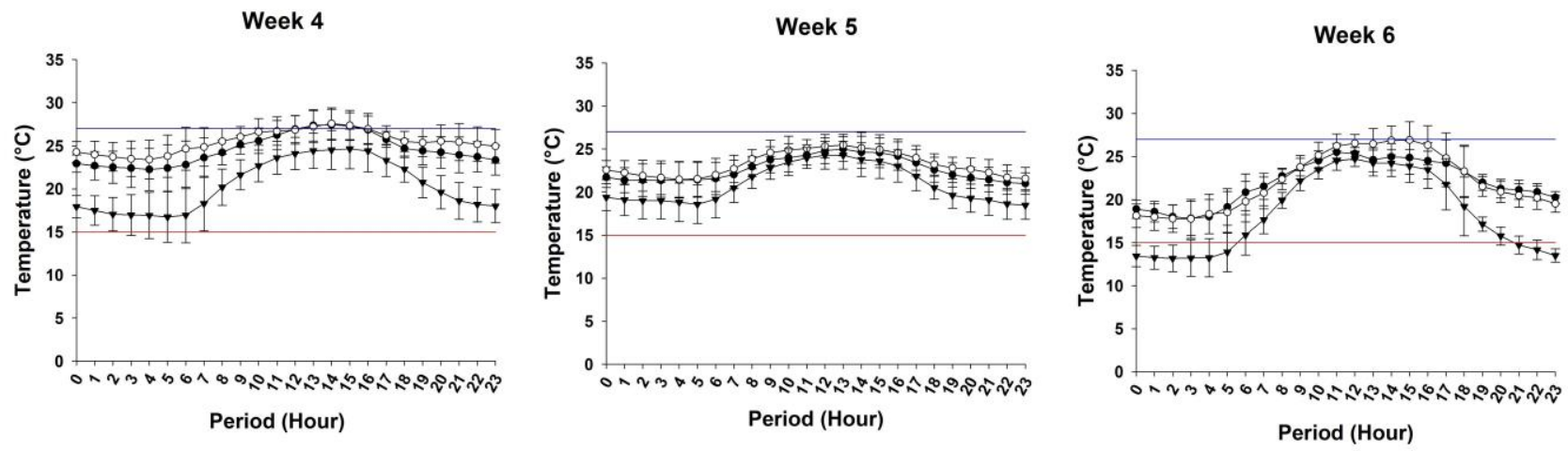

Summer
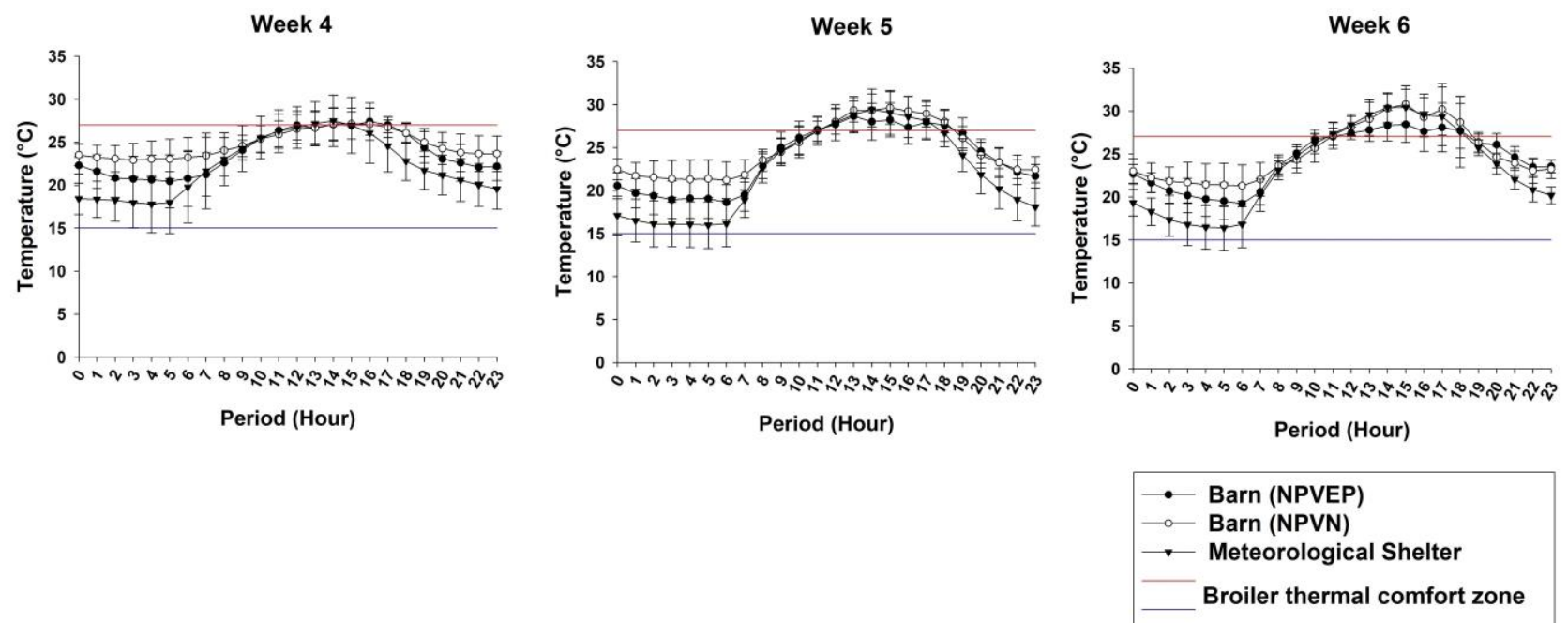

FIGURE 4. Relationship between the average hourly inside and outside temperatures and the temperature range recommended by Tinôco (2001) and Medeiros et al. (2005) during growout in the three evaluated flocks.

It can be observed from Figure 4 that in the flocks evaluated during winter and spring, the average hourly temperatures recorded inside both barns are consistently within the recommended range, except for a few early afternoon hours during week 4 of the spring flock in the NPVN barn. In the summer, during the last two weeks of growth, the mid-day temperatures exceed the upper limit of the comfort range for birds at this age. The observed temperature values above the recommended limit for broiler comfort are recorded when the outside temperature is highest, between 12 a.m. and 6 p.m., showing that as the barns are not thermally insulated, the external temperature has a strong influence on the internal environment of the barn.

For the summer flock, during the period where the internal temperatures in the barn were above the comfort range for the birds, the barn temperature was found to be less than the outside temperature. This occurred more frequently in the NPVEP barn than in the NPVN barn, suggesting that during these periods the evaporative cooling systems were functioning to limit the heat stress.

As can be seen in Figure 4, during some periods of the day in the summer flock, the average indoor 
temperature in both poultry houses studied is above the comfort range for birds at this age. Although it is very difficult to maintain the internal conditions in the barns within the range of thermal comfort for the birds throughout the housing period, it is important to limit the high temperature for the good broiler performance because birds tend to suffer behavioral and physiological changes, as described by Lopes et al. (2015), Silva et al. (2015), and Navas et al. (2016) during heat stress.

The lineage manual (Hubbard, 2016) for the broilers raised in these barns suggests a temperature range of $18-27{ }^{\circ} \mathrm{C}$ during growout. The controller of the environmental control system of these barns was programmed for a temperature range of $20-25{ }^{\circ} \mathrm{C}$ inside the barns during growout. Taking these values into account, it can be seen that the most critical season for the broilers creation was the summer, where it is possible to observe that in both barns the average hourly temperatures recorded were above the broilers comfort range during the most critical time of day (10 a.m. to 4 p.m.), where outside temperatures were highest.

Although the environmental control system of these barns was programmed to maintain the internal temperature in the range of $20-25{ }^{\circ} \mathrm{C}$ during growout, studies presented in the literature show that it is possible to work with a higher upper limit of the broiler thermal comfort without compromising their productive performance. Medeiros et al. (2005) found in their study that during the growout phase $(22-42 \mathrm{~d})$ birds showed good production responses based on productive performance (weight gain, feed consumption, feed conversion efficiency), mortality, and physiological and behavioral responses, at environmental conditions with temperatures in the range of $26^{\circ} \mathrm{C}$, relative humidity of 55 $\%$, and air velocity of $1.5 \mathrm{~m} . \mathrm{s}^{-1}$. Arcila (2014) studied different temperatures $\left(25,28,31,34\right.$, and $\left.37{ }^{\circ} \mathrm{C}\right)$ for broilers during growout, and found that the best performance results were obtained at $28{ }^{\circ} \mathrm{C}$.

Regarding the lower limit of the thermal comfort range of birds during growout, Tinôco (2001) pointed out that birds can tolerate minimum temperatures as low as 15 ${ }^{\circ} \mathrm{C}$. This is possible because, during growth, the birds have a greater capacity to withstand cooler temperatures because their thermoregulatory system is more developed, which facilitates their homeothermic control.

Considering that the studies presented in the literature indicate that birds during growout can tolerate higher temperatures $\left(27-28^{\circ} \mathrm{C}\right)$ than those traditionally employed $\left(25^{\circ} \mathrm{C}\right)$, it is possible for poultry farmers to better manage the environment control system of the barns and reduce the electrical energy consumed. Thus, any possibility of energy conservation that can reduce operating costs without compromising the bird productivity should be considered by poultry farmers to seek the best cost-benefit ratio for their production system.

In addition to the analysis of the temporal variation of the internal temperature of the broiler houses, the spatial variation of the environmental conditions in barns is another parameter that helps in the evaluation of the efficiency of the ventilation system used in poultry facilities. In Figure 5, the spatial variation of the average temperature data recorded at each point during growout in both broiler houses and all three evaluated flocks is shown graphically. 


\section{Winter}
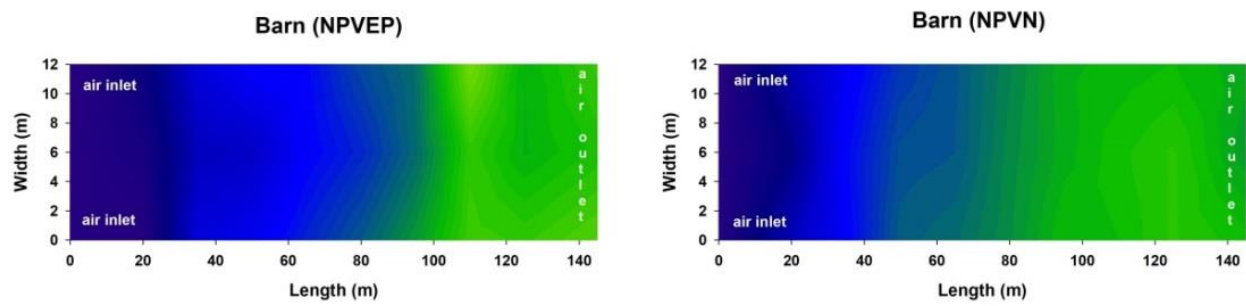

Spring
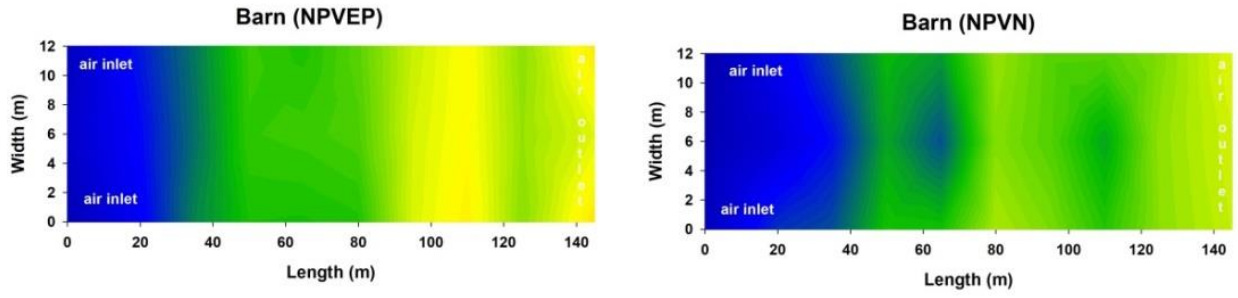

Summer
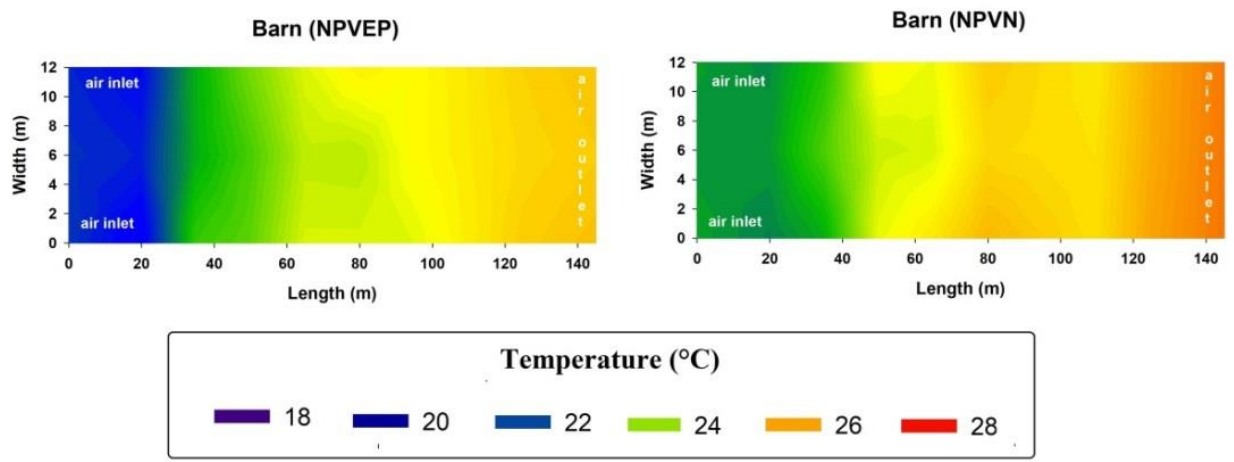

FIGURE 5. Spatial variation of the average temperature recorded in the Barn (NPVEP) and Barn (NPVN), in the flocks evaluated in winter, spring, and summer.

It can be seen from Figure 5 that the average air temperature recorded inside both barns during growout increases gradually in the direction of air flow, that is, from the direction of air inlets to the exhaust fans. This difference was $4.5,4.6$, and $4{ }^{\circ} \mathrm{C}$ in the Barn (NPVEP) and $4.2,4.1$, and $4{ }^{\circ} \mathrm{C}$ in the Barn (NPVN), in winter, spring, and summer, respectively. According to Coelho (2018), these values are considered very high, since maximum gradients of up to $3{ }^{\circ} \mathrm{C}$ are generally allowed for broiler houses with good conditions.

According to Hernandez et al. (2016), the increase in temperature along the barn can be explained by the use of tunnel ventilation, which when activated, promotes the displacement of air from the inlet air region towards the exhaust fans (air outlet). This airflow carries with it the metabolic heat and moisture produced by the birds housed there, plus the thermal loads generated by equipment, and from the solar radiation emitted through the cover and the side closures. This longitudinal temperature gradient observed may negatively affect the final uniformity of the flock, since the productive performance of the birds is influenced by the thermal conditions of the environment where they are housed; those birds near the tunnel fans experience high temperatures, and this may result in financial losses to poultry farmers (Coelho, 2018).
According to Silva et al. (2013), even if the average temperature values inside the barns are within the considered range of comfort for the birds, an uneven productivity performance of the flock may result in financial losses if the thermal gradient along the barn is too high. These researchers studied the spatial variability of the thermal environment in broiler houses with negative pressure ventilation systems associated with evaporative pad using misting nozzles, and found the average temperatures inside the facility to be approximately $28{ }^{\circ} \mathrm{C}$, with extremes ranging from $25.5{ }^{\circ} \mathrm{C}-32.2^{\circ} \mathrm{C}$, at the critical time between 12 p.m. and 3 p.m, when the birds were $42 \mathrm{~d}$ old. This was eventually reflected in an unevenness in the final weight of the flock of the evaluated animals.

A possible solution to reduce the longitudinal temperature gradient observed in these barns would be to invest in some insulation, especially for the roof. According to Abreu et al. (2007) and Machado et al. (2012), the high incidence of solar radiation on the broiler house roof is one of the main causes of thermal stress in broiler facilities, contributing to the increase in the heat throughout the installation. Coelho (2018) points out that compared to the insulation of the side walls, be they solid walls or curtains, the thermal insulation of the roof is a better investment, since the largest radiant load is incident through the roof. Additionally, the design of an 
evaporative cooling system (pad inlet area, nozzle pressure, and evaporative efficiency) is critical. The longitudinal gradient can be reduced with greater ventilation rates.

Regarding the ventilation rates employed in poultry facilities, it is observed that these have a fundamental role in maintaining the appropriate temperature in the barns. Oliveira et al. (2020) highlighted that the knowledge of bioenergetics and ventilation rate in livestock facilities are fundamental for the correct design and efficient operation of these facilities.

According to Ranjan et al. (2019), the use of adequate ventilation systems in poultry facilities provides consistent airflow patterns, with well-designed tunnel ventilation provideing high airflow speeds and facilitating heat loss of broilers to the environment through convective exchanges, thereby reducing their body temperature. It is important to note, however, that according to the literature, the ideal wind speed recommended for broilers in the final stage of the production cycle varies from 2 to $2.5 \mathrm{~m} . \mathrm{s}^{-1}$ (Curi et al., 2014b).

For the correct dimensioning and management of the ventilation system, in addition to the adequate choice of fans / exhaust fans providing an appropriate air flow for the proposed system, another element of great importance for the correct use of the ventilation system is the provision of the air entrance. According to Ma \& Zou (2020), these inlet air devices, when well designed and optimized, help to improve the air flow in the installation, thus influencing environmental factors in the barn, such as the temperature distribution, wind speed distribution, and the concentration of gases.

\section{CONCLUSIONS}

Using the thermal comfort range for broilers during brooding in the present study, it was found that for most of the time, the average hourly temperatures recorded in the broiler occupied zone exceeded this range for all three flocks evaluated (winter, spring, and summer). This suggests that it is possible for broiler farmers to adapt to an improved management of the heating system for reducing heating costs.

During the growout phase in winter and spring, it was observed that when the external temperature was milder, the average hourly temperatures in both barns were within the recommended range for broiler comfort. However, in summer, it was observed that, due to the increase in the external temperature, there was an increase in the temperature in both studied barns, indicating that the thermal insulation or the thermal conditioning system of the facilities was not adequate to withstand such a situation.

\section{ACKNOWLEDGMENTS}

The authors would like to thank Coordenação de Aperfeiçoamento de Pessoal de Nível Superior - CAPES for the scholarship. This study was financed in part by the Coordenação de Aperfeiçoamento de Pessoal de Nível Superior - Brasil (CAPES) - Finance Code 001

\section{REFERENCES}

Abreu VMN, Abreu PG (2011) Os desafios da ambiência sobre os sistemas de aves no Brasil. Revista Brasileira de Zootecnia 40:1-14.
Abreu PG, Abreu VMN, Coldebella A, Jaenisch FRF, Paiva DP (2007) Condições térmicas ambientais e desempenho de aves criadas em aviários com e sem o uso de forro. Arquivo Brasileiro de Medicina Veterinária e Zootecnia 59(4):1014-1020.

Arcila JCP (2014) Desempenho zootécnico e fisiológico de frangos de corte, na fase final de crescimento, submetidos a diferentes níveis de estresse por calor. Dissertação Mestrado, Viçosa, Universidade Federal de Viçosa.

Bueno L, Rossi LA (2006) Comparação entre tecnologias de climatização para criação de frangos de corte quanto a energia, ambiência e produtividade. Revista Brasileira de Engenharia Agrícola e Ambiental 10(2):497-504.

Cândido MGL, Tinôco IFF, Pinto FAdeC, Santos NT, Roberti RP (2016) Determination of thermal comfort zone for early-stage broilers. Engenharia Agrícola, 36(5):760-767.

Cassuce DC, Tinôco IFF, Baêta FC, Zolnier S, Cecon PR, Vieria MFFA (2013) Thermal comfort temperature up date for broiler chicken up to 21 days of age. Engenharia Agrícola 33(1):28-36.

Coelho DJR (2018) Ambiente térmico e aéreo de aviários sólidos de frangos de corte acondicionados artificialmente para condições climáticas do Brasil e de Portugal. Tese Doutorado, Viçosa, Universidade Federal de Viçosa.

Costa EMS, Dourado LRB, Merval RR (2012) Medidas para avaliar o conforto térmico em aves. PUBVET 6(31).

Curi TMRC, Vercellino RA, Massari JM, Souza ZM, Moura DJ (2014a) Geoestatistica para a avaliação do controle ambiental do sistema de ventilação em instalações comerciais para frangos de corte. Engenharia Agrícola 34(6):1062-1074.

Curi TMRC, Moura DJ, Vercellino RA (2014b)

Ventilação de precisão. Revista Produção Animal Avicultura, 81:32-36. Available:

https://www.avisite.com.br/revista/pdfs/revista_edicao_81. pdf. Accessed: Jun, 2020.

Hernandez RO, Tinôco IFF, Saraz JAO, Mendes LB, Rocha KSO, Garcia LMG (2016) Thermal environment in two broiler barns during the first three weeks of age. Revista Brasileira de Engenharia Agrícola e Ambiental 20(3):256-262.

Hubbard (2016) Broiler management - Manual fast growth. Available:

https://www.hubbardbreeders.com/media/manual_broiler_ management_en__013796700_1441_27062016.pdf. Accessed: Jun, 2019.

Lopes JCO, Ribeiro MN, Lima VBS (2015) Estresse por calor em frangos de corte: Avicultura, desempenho, infraestrutura, nutrição, temperatura. Nutritime Revista Eletrônica 12(6):4478-4487.

Ma YX, Zou HF (2020) Optimized design o fair inlet devices based on environment analysis of a broiler house model. IOP Conf. Series: Materials Science and Engineering. DOI: http://dx.doi.org/10.1088/1757899x/789/1/012036 
Machado NS, Tinôco IFF, Zolnier S, Mogami CA, Damasceno FA, Zeviani WM (2012) Resfriamento da cobertura de aviários e seus efeitos na mortalidade e nos índices de conforto térmico. Nucleus 9(2):59-73.

Mascarenhas NMH, Costa ANL, Pereira MLL, Caldas ACA, Batista LF, Gonçalves EL (2018) Thermal conditioning in the broiler production: challenges and possibilities. Journal of Animal Behaviour and Biometeorology 6:52-55.

Medeiros CM, Baêta FC, Oliveira RFM, Tinôco IFF, Albino LFT, Cecon PR (2005) Efeitos da temperatura, umidade relativa e velocidade do ar em frangos de corte. Engenharia na Agricultura 13:277-286.

Navas TO, Oliveira HF, Carvalho FB, Stringhini JH, Café MB, Filho PH (2016) Estresse por calor na produção de frangos de corte: Ambiência, avicultura industrial, conforto térmico, desempenho. Nutritime Revista Eletrônica 13(1):4550-4557.

Neves DP, Nääs IA, Baracho MS (2010) Ambiente de alojamento e equipamentos de alimentação na avicultura industrial brasileira - Uma revisão. Revista Brasileira de Engenharia de Biossistemas 4(1):01-11.

Oliveira JL, Ramires BC, Xin H, Wang Y, Hoff SJ (2020) Ventilation performance and bioenergetics of dekalb 10hite hens in a modern aviary system. Biosystems Engineering (Special Issue). DOI:

https://doi.org/10.1016/j.biosystemseng.2020.03.014

Oliveira RFM, Donzele JL, Abreu MLT, Ferreira RA, Vaz RGMV, Cella OS (2006) Efeitos da temperatura e da umidade relativa sobre o desempenho e o rendimento de cortes nobres de frangos de corte de 1 a 49 dias de idade. Revista Brasileira de Zootecnia 35(3):797-803.

Plasson do Brasil (2020) Exaustores 50. Available: http://www.plasson.com.br/livestock/site/products/chicken /product/11. Accessed: Jun, 2020.
Ranjan A, Sinha R, Devi I, Rahin A, Tiwari S (2019) Effect of Heat Stress on Poultry Production and their Managemental Approaches. International Journal of Current Microbiology and Applied Sciences 8(02):15481555. DOI: https://doi.org/10.20546/ijcmas.2019.802.181

Santos PA, Baêta FC, Tinôco IFF, Albino LFT, Cecon PR (2009) Ventilação em modo túnel e lateral em galpões avícolas e seus efeitos no conforto térmico, na qualidade do ar e no desempenho das aves. Revista Ceres 56(2):172-180.

Santos MP, Vale MM, Branco T, Klein DR, Santos JPA (2017) Heat stress in broilers and the need of climatization systems. Brazilian Journal of Biosystems Engineering 11(3):265-272.

Schmidt NS, Silva CL (2018) Pesquisa e desenvolvimento na cadeia produtiva de frangos de corte no Brasil. Revista de Economia e Sociologia Rural 56(3):467-482.

Schiassi L, Yanagi Junior T, Ferraz, PFP, Campos AT, Silva GRE, Abreu LHP (2015) Comportamento de frangos de corte submetidos a diferentes ambientes térmicos. Engenharia Agrícola 35(3):390-396.

Silva RC, Rodrigues LR, Rodrigues VP, Arruda AS, Souza BB (2015) Análises do efeito do estresse térmico sobre a produção, fisiologia e dieta de aves. Agropecuária Científica no Semiárido 11(2):22-26.

Silva EG, Santos AC, Ferreira CLS, Sousa JPL, Rocha JML, Silveira Junior O (2013) Variabilidade espacial das características ambientais e peso de frangos de corte em galpão de ventilação negativa. Revista Brasileira de Saúde e Produção animal 14(1):132-141.

Silva IJO, Vieira FMC (2010) Ambiência animal e perdas produtivas no manejo pré-abate: o Caso da Avicultura de Corte Brasileira. Archivos de Zootecnia 59(R):113-131.

Tinôco IFF (2001) Avicultura Industrial: Novos Conceitos de Materiais, Concepções e Técnicas Construtivas Disponíveis para Galpões Avícolas Brasileiros. Revista Brasileira Ciencia Avicola 3(1):01-26. 